\title{
ПСИХОЛОГІЧНІ ОСОБЛИВОСТІ СПІЛКУВАННЯ МЕДИЧНОЇ СЕСТРИ І ПАЦІЄНТІВ ІЗ ПОЗИЦІЙ МЕДИЧНОЇ ДЕОНТОЛОГІЇ
}

\author{
Є. В. Тишкевич-Львова \\ Тернопільський національний медичний університет \\ імені І. Я. Горбачевського МОЗ України
}

У статті висвітлено проблему вибудовування комунікації сестринського персоналу 3 пацієнтами, підкреслено принципове значення спілкування для лікувального процесу. Відображено значущість вміння медичної сестри зрозуміти і вислухати пацієнта, що здійснює сприятливий вплив на встановлення психологічного контакту.

\section{PSYCHOLOGICAL FEATURES OF COMMUNICATION BETWEEN NURSES AND PATIENTS FROM THE POSITIONS OF MEDICAL DEONTOLOGY}

\author{
Ye. V. Tyshkevich-Lvova
}

\section{Horbachevsky Ternopil National Medical University}

The article deals with the problem of establishing of communication between the nursing staff and their patients. It emphasizes the vital role of communication in the direct care. The importance of the nurse's ability to understand and listen to the patient, which has a beneficial effect on establishing psychological contact is reflected.

Вступ. На взаємини медицини і суспільства впливають дві протилежні позиції. Прихильники першої вважають, що громадська думка гальмує прогрес медицини [4]. Прихильники другого підходу переконані, що розвиток медицини порушує гармонійну єдність природи і людини, є основною причиною ослаблення людства загалом і навіть може спричинити його до «виродження» [3]. Однак медицина і суспільство не протистоять один одному, перебуваючи в складній взаємодії. Медицина вільно чи мимоволі впливає на суспільство, змінюючи його. Від дотримання медичних норм у різних сферах діяльності людей залежать життя і здоров'я кожного, і суспільство зацікавлене їх враховувати.

Однак і суспільство диктує медицині свої вимоги. Вони гальмують їі розвиток, але в розумних межах, адже результат будь-якого процесу, якщо він відбувається безконтрольно, непередбачуваний, а інколи й трагічний. Під тиском громадськості лікарі вже в XX ст. почали з особливою суворістю підходити до впровадження в лікувальну практику нових лікарських препаратів. У результаті з'явилися закони

(с) Є. В. Тишкевич-Львова, 2021 «медицини доказів», якими тепер керуються медики усього світу [6]. Підвищення цінності людського життя вплинуло на сучасну медичну етику і деонтологію, спричинило законодавче закріплення прав пацієнта.

Основна частина. Нині все більше завойовує свої позиції гуманістична медицина, згідно з якою у процесі лікування відводиться важливе місце гуманному ставленню, взаємоповазі та емоційній взаємодії між медичним працівником і пацієнтом. Ключовими в лікуванні та реабілітації $є$ етичне виховання, деонтологічні позиції медичних працівників, оскільки більшу частину лікувального процесу пацієнт перебуває під наглядом медичної сестри. Медична деонтологія і професійна етика особливо важливі в медицині, юриспруденції, педагогіці, журналістиці, тобто там, де виконання професійних обов'язків торкається вищих людських цінностей життя, здоров'я, свободи, гідності, особистої недоторканності [5]. Найбільш виражена і авторитетна традиція професійної етики сформувалася в медицині. У всьому світі залишається значущою медична етика давньогрецького лікаря Гіппократа; безумовна повага до людського життя; як мінімум, неспричинення йому шкоди; конфіденційність; обе- 
режність в інформуванні пацієнта. Медична етика вимагає від фахівця не нашкодити: «У який би дім я не зайшов, я увійду туди для користі хворого» говориться в Клятві Гіппократа [1].

Медична етика - це вчення про роль моральних принципів у діяльності медичних працівників, про їх високогуманне ставлення до людини як необхідну умову успішного лікування. Предметом спостереження медичної етики є психоемоційний аспект діяльності лікаря, медичної сестри, лаборанта, молодшого медичного персоналу [3]. Медична етика розглядає:

- ставлення до людини, у якої $\epsilon$ проблеми зі здоров'ям;

- залежність моральної поведінки медичного працівника від умов професійної діяльності;

- норми поведінки медичного працівника, його культури, фізичну і моральну охайність [7].

Медична деонтологія $\epsilon$ комплексом етичних норм, принципів, якими керується медпрацівник; сукупність професійних, морально-етичних і правових принципів і правил, що становлять поняття «обов'язок медичного працівника» [3]. Аспектами медичної деонтології $€$ : взаємовідносини медичних працівників із пацієнтами, взаємовідносини медичних працівників з родичами пацієнтів, взаємовідносини медичних працівників між собою. Дотримання етики і деонтології в медицині завжди має велике значення. Це зумовлено специфікою роботи персоналу лікувальних закладів.

Усі пацієнти мають право на отримання високоякісної медичної допомоги, яку повинні забезпечувати медичні працівники. Значну роль у цьому процесі відіграють добрі взаємини з пацієнтами та колегами, дотримання правил професійної етики. Тому сучасному суспільству потрібні медичні сестри, які володіють міцними професійними знаннями і моральними принципами медичної професії. Етичною основою професійної діяльності медичної сестри є гуманність і милосердя. Тому найважливішими завданнями професійної діяльності медичної сестри $є$ комплексний всебічний догляд за пацієнтами і полегшення їх страждань; відновлення здоров'я та реабілітація; сприяння зміцненню здоров'я та запобігання захворюванням.

Однією з основ лікувальної діяльності $\epsilon$ вміння медичної сестри зрозуміти і вислухати пацієнта, що здійснює сприятливу дію на встановлення психологічного контакту. Необхідно враховувати характер захворювання, особливо хронічних випадків, що вимагають тривалого лікування і спостереження, що у контакті з пацієнтом має важливе значення. Безсумнівно, така зацікавленість здатна впливати на процес взаємовідносин сестринського персоналу і пацієнта.

Ізоляція від сім'ї (в стаціонарі) та звичної професійної діяльності, занепокоєння за стан власного здоров'я викликають у пацієнта різні психогенні реакції. Внаслідок психогеній може погіршуватися основне соматичне захворювання, що водночас ускладнює психічний стан пацієнтів. Різні скарги, етичні проблеми, що виникають, вказують на відсутність необхідних психологічних знань і практики відповідного спілкування медичних працівників 3 пацієнтами. Медичній сестрі необхідно постаратися відчути переживання пацієнта, зрозуміти та оцінити їх, відшукати причини тривоги, водночас їі реакція повинна бути резонансом на почуте.

Особливості особистості медичної сестри, так само як й індивідуальні особливості пацієнта, його психіки, впливають на встановлення позитивних психологічних відносин і довіри між ними. Відповідальність за характер цих взаємин, таких важливих для успішного лікування, лягає на медичного працівника. Ефективність лікування значною мірою залежить від віри пацієнта в одужання, що, водночас, тісно пов'язано з тим рівнем довіри, яку він відчуває до лікаря і персоналу відділення [2]. Довіра до медичної сестри основана на першому враженні пацієнта: значення мають міміка, жестикуляція, тон голосу, вираз обличчя, манера розмови, зовнішній вигляд. Медична сестра заслуговує на довіру пацієнта в тому випадку, якщо вона спокійна, впевнена, але не гордовита, якщо манера поведінки - наполеглива та рішуча - супроводжується людяністю і делікатністю. Необхідно дати зрозуміти пацієнтові, що медичних працівників, до яких він звернувся за допомогою, цікавлять не лише питання діагностики, а й особистість самої людини [8].

Прямий обов'язок медичних працівників - усунути перешкоду в контакті з пацієнтом, викликати його довіру, основану на участі та душевному теплі. Довіра пацієнта до медицини може бути серйозно підірвана в тому випадку, якщо він помітить, що між лікарем і медичною сестрою напружені відносини, якщо сестра під час прийому допускає репліки, що не стосуються справи, не чітко виконує розпорядження лікаря [2].

Діяльність медичної сестри підпорядкована особливим вимогам - бути терплячою і вміти володіти собою. Це пов'язано з великим емоційним напружен- 
ням, що виникає у спілкуванні з пацієнтами, особливо з підвищеною дратівливістю, вимогливістю, болючою вразливістю. Тому необхідно передбачати різні варіанти розвитку захворювання, якщо стан здоров'я пацієнта не покращується. У певних ситуаціях доречно проявити почуття гумору, однак без глузування, іронії та цинізму. Необхідно відзначити, що деякі пацієнти не розуміють жартів, сказаних із кращими намірами, і сприймають їх як неповагу i приниження гідності.

Робота сестринського персоналу багата «колекцією» ситуацій, має динаміку і певні суперечності. Особливості медицини полягають не лише в зовнішньому аспекті умов діяльності, а, передусім, в їх смисловій значущості в долі людини. Совісність і порядність, великодушність та доброзичливість, благородство й увага, тактовність і ввічливість у всьому, що стосується життя та здоров'я пацієнта, повинні виступати як звичні, повсякденні норми поведінки. Незважаючи на встановлення контакту і подальший розвиток позитивних взаємовідносин між медичною сестрою і пацієнтом, ці відносини можуть ускладнюватися деякими негативними рисами характеру медичного працівника (гнівом або, навпаки, замкнутістю зі слабкими емоційними реакціями). Авторитет може бути підірваний, якщо у пацієнта складається враження, що медсестра, наприклад, погано відгуку-

\section{СПИСОК ЛІТЕРАТУРИ}

1. Бачинська Л. Ю. Співвідношення медичної етики, медичної деонтології та біоетики / Л. Ю. Бачинська // Науковий вісник Ужгородського національного університету. - 2016. - Вип. 37 (3). - С. 131-134. - (Серія «Право»).

2. Іванчук О. В. Особливості комунікативної взаємодії медичної сестри та геріатричних хворих / О. В. Іванчук, А. О. Боб // Медсестринство. - 2017. - № 3. - С. 33-36.

3. Касевич Н. М. Медсестринська етика і деонтологія : підручник / Н. М. Касевич. - 3-тє вид., випр. - К. : ВСВ «Медицина», 2013. - 200 с.

4. Пасєчко Н. В. Основи сестринської справи : підручник / Н. В. Пасєчко. - Тернопіль : Укрмедкнига, 2002. 544 c. ється про колег у присутності пацієнтів, зарозуміло ставиться до підлеглих і догоджає перед начальством, відсутня самокритика.

Як доцільно зазначає С. Поплавська, істотну роль в діяльності медичних сестер відіграє не лише зовнішній вигляд, а й психологія спілкування з пацієнтом. На жаль, люди, які перебувають в стаціонарі, далеко не завжди задоволені рівнем спілкування медсестер з ними, їм доводиться стикатися з байдужістю і навіть їх черствістю, недостатністю уваги [5]. Саме особистісні характеристики медичних працівників середньої ланки відіграють істотну роль у взаєминах із пацієнтами. Серед якостей, якими повинна володіти хороша медсестра, є уважність, старанність, терпимість, чуйність, врівноваженість, товариськість і дбайливість.

Висновки. У лікувальному процесі розрізняють кілька видів спілкування між пацієнтом і медичною сестрою, і від фахівця значною мірою залежить, який вид спілкування буде встановлено. Однак у будь-якому випадку необхідно дотримуватися певної тактики стосовно пацієнта, щоб заслужити його довіру до себе. Отже, особистість медичної сестри, стиль і методи ії роботи, вміння впливати на пацієнтів і спілкуватися з ними - важливий елемент не лише лікувального процесу, а й психологічного спілкування медичного працівника з пацієнтом.

5. Поплавська С. Д. Етика професійної взаємодії медпрацівника і хворого / С. Д. Поплавська // Комп'ютерноінтегровані технології: освіта, наука, виробництво. 2013. - № 11. - С. 126-135.

6. Психологічні аспекти медичної праці : навч. посіб. / [уклад. І. В. Федік]. - К. : ДП «Видавничий дім «Персонал», 2017. - 126 c.

7. Bitzer E. M. Health Literacy and patient education in medical rehabilitation / E. M. Bitzer, U. Sporhase // National Center for Biotechnology Information. - 2015. - Vol. 58 (9). P. 983-988.

8. Branch W. T.Jr. Treating the whole patient: passing timehonoured skills for building doctor-patient relationships on to generations of doctors / W. T. Jr. Branch // Medical Education. - 2014. - Vol. 48. - P. 67-74. 